\title{
THE SIGNIFICANCE OF THE BLACK SEA COUNTRIES OF THE THREE SEAS INITIATIVE RELATIONS WITH THE UNITED ARAB EMIRATES
}

\author{
Adam KRZYMOWSKI, PhD
}

Zayed University, UAE

ak7@vp.pl

\begin{abstract}
The Black Sea region has strategic geopolitical importance where the routes of Europe, the Caucasus, Asia, and the Middle East intersect. Ensuring stability and security in the Black Sea area is essential for emerging new security architecture. In search of balance, the challenges are met by the Three Seas Initiative (3SI) and the deepening of strategic relations with the United Arab Emirates. The UAE, anchored in the Euro-Atlantic partnership and with extensive influence, emerges as an interesting strategic partner. When analysing the Three Seas Initiative, it should be noted that the United States of America joined the implementation of 3SI, seeing it as an opportunity to pursue American interests in LNG markets, and in a broader geopolitical dimension, combining this initiative with projects in the Middle East. This research paper is the first to analyse the foreign and security policy of the two Black Sea countries, Bulgaria, and Romania that participate in the Three Seas Initiative, from the geostrategic perspective and relations with the United Arab Emirates. The research work is based on empirical research, and the results of which are largely derived from 10 years of direct observation, as well as the participation of the author of the article in many initiatives related to cooperation between all 3SI countries with the United Arab Emirates, among others as an Ambassador, Senior Advisor at Dubai Expo 2020.
\end{abstract}

Keywords: Black Sea, United Arab Emirates, Three Seas Initiative, 3SI, Bulgaria, Romania.

\section{Introduction}

The Three Seas Initiative (3SI), announced in 2015 and formally initiated in 2016, is a new form of strategic cooperation between the 12 countries located between the Adriatic, the Baltic, and the Black Seas. Due to the immediate vicinity of this area with Russia, Turkey, the Mediterranean basin, and the proximity of the Middle East, as well as the strategic activity of the USA and China with all countries of this initiative, 3SI has a global dimension. The Black Sea 
region has strategic geopolitical importance where the routes of Europe, the Caucasus, Asia, and the Middle East intersect. Therefore, this region shows both great opportunities for beneficial cooperation with Asia and the Middle East and vulnerability to threats arising from these areas. It is of key importance for the stabilisation and security of Europe, including the Common Foreign and Security Policy of the European Union. In this region, there are still active conflicts in Crimea and Georgia, and competition for strategic energy projects. On the other hand, Russia, and Turkey conduct military operations in Syria. In addition, Bulgaria and Romania, the Black Sea countries, the European Union, and NATO members have been participating in the Three Seas Initiative (3SI), being of fundamental importance for its implementation. Thus, the Black Sea region is an area of rivalry between the USA, Russia, Turkey, and the EU with the mutual influence of the Middle East (Joja, 2020).

Through the annexation of Crimea, Russia acquired most of the Ukrainian oil and gas fields located in the Black Sea. On the other hand, Turkey, by sending refugees from the Middle East to Bulgaria, may contribute to the destabilisation of this country with consequences for the entire EU area. Therefore, ensuring stability and security is essential in the Black Sea area to the emerging new security architecture. Conflicts between Turkey and other NATO members over its military engagement in the Mediterranean Sea, along with Russia, as well as the lack of unanimity among European Union members on the future of the Western Balkans, and the rivalry between the USA and China in terms of infrastructure investment, will contribute to many tensions in the structure of the global order. In such a situation, in search of a balance of power, these challenges are met by the Three Seas Initiative and the deepening of strategic relations with the United Arab Emirates.

Russia is demonstrating its imperial goals by increasing its military forces as well as its control over territories in the Black Sea region. This game is very dangerous for the entire architecture of global security. Russia has taken actions not only against countries aspiring to the Euro-Atlantic political, economic, and military structures, but also tries to get the support of Bulgaria, the EU, and NATO member, or Turkey, which is a member of the Alliance North Atlantic and allows Russia to take a hegemonic position in the region (Joja, 2019, pp. 2-3). In such an arrangement, the allied solidarity, which is the basis of the North Atlantic Treaty Organisation, is naturally broken. Moreover, Russia's increasing influence in the Black Sea basin is part of a broader Eurasian strategy. It is an element serving to increase presence, influence, and power in 
the Mediterranean region as well as in the Middle East. One example is Russia's military cooperation with Turkey in Syria or Russia's activity in Libya in another constellation of interests.

Turkey joined NATO in 1952 to stop the imperial plans of the Soviet Union towards the Black Sea and the Middle East. Turkey has always wanted a dominant position in the region. Several months after the collapse of the Soviet Union, to maintain Turkey's leading role and importance in the region, in 1992 Ankara initiated the establishment of the Black Sea Economic Cooperation Organisation (BSEC). However, it was not an effective tool for implementing Turkey's foreign and security policy. Therefore, after nearly 20 years, the concept of 'strategic depth' of the Justice and Development Party (AKP) was adopted, which is now consistently being implemented. One of the assumptions of this doctrine is to use the geographical location of Turkey to build the main energy corridors in its area (Krzymowski, 2019, p. 322). In 2015, after the Turkish military forces shot down a Russian attack aircraft, the situation between Russia and Turkey was very tense. However, fairly quickly, after the failed military coup attempt in 2016 and the dramatic rise of anti-American sentiment in Turkey, which led to the USA being perceived as the main security threat, Ankara decided to enter into a strategic alliance with Moscow.

This article is the first to analyse the foreign and security policy of the two Black Sea countries that participate in the Three Seas Initiative, Bulgaria, and Romania, from the geostrategic perspective and relations with the United Arab Emirates. The research work is based on empirical research, and the results which are largely derived from 10 years of direct observation, as well as the participation of the author of the article in many initiatives related to cooperation between the countries of the Three Seas Initiative and the United Arab Emirates, including as Ambassador, Senior Advisor is Dubai Expo 2020 also responsible for the strategies and dynamization of all 3SI countries (except Poland) in UAE relations.

Therefore, the methods of empirical research, with particular emphasis on qualitative methods and inductive reasoning, were considered the most appropriate in finding an answer to the research question about the role and importance of cooperation between Bulgaria and Romania with the United Arab Emirates for the effective implementation of the Three Seas Initiative. For this purpose, the methods of document content analysis, case studies, comparative analysis, observation, and interviews were used. In this context, game theory and the theory of institutionalism were also useful. In addition, the author adopted Wendt's (1987) concepts, combining rationalist and reflection approaches. Thus, this article, using the above-mentioned 
methods, both explains international relations in the topic discussed and shows the basis of the values of interests that shape changes. In addition, scientific realism combined with liberal institutionalism was applied in complement. The author of this article shows that despite the European integration process, including the Three Seas Initiative (all states are EU members), it should be recognized that states with their interests are the most important. Therefore, states, being rational entities, should be primarily analysed. In this way, it will be possible to explain the ongoing integration processes and see the real game of interests.

\section{Bulgaria and Romania relations with the United Arab Emirates}

Romania established diplomatic relations with the United Arab Emirates on August 1, 1989. Moreover, in less than a year, in June 1990, the Romanian Embassy was opened in the UAE capital, Abu Dhabi. Already in May 1991, the Romanian Prime Minister, Petre Roman, paid an official visit to the United Arab Emirates. On October 19, 1991, diplomatic relations were established between Bulgaria and the United Arab Emirates. In January 1992, the Romanian Consulate General in Dubai began its activity. On the other hand, in April 1993, the official visit of the President of Romania, Ion Iliescu, took place in the UAE. Thus, the first years of diplomatic relations were marked by visits to the United Arab Emirates at the highest level of Romanian leaders, including the president and prime minister. However, the following years of relations between the Romania and the UAE were characterised by their stable development, with consultations between the ministries of foreign affairs of both countries, but without visits at the highest level. In the case of Bulgaria, the 90 s was a period that is not characterized by any dynamics in relations between the two countries.

The beginning of the $21^{\text {st }}$ century brought more interest to Bulgaria and Romania in bilateral relations with the United Arab Emirates and vice versa. Bulgaria's diplomatic mission, in the form of the General Counsellor in Dubai, was opened in 2001. The relationship between Romania and the United Arab Emirates once again reached a deeper level when in February 2002 the Romanian President, Ion Iliescu, re-elected to the office, paid another official visit to the UAE. This presidential visit influenced the decision by the Emirati company Dubai Ports World on a strategic investment in Romania. A few months after the war started in Iraq, in November 2003 Bulgarian President Georgi Parvanov paid an official visit to the United Arab Emirates. At the same time, the Dubai-based DP World corporation dealing with cargo logistics and servicing 
seaport terminals received in November 2003 a long-term license to operate the Constanta South Container Terminal (CSCT) SRL. The facility is a modern and most important container terminal located in the Black Sea. This terminal is crucial not only for Romania's needs but also for a large part of Central and Eastern Europe. Therefore, it fits perfectly into the strategies of the Three Seas Initiative, for which the transport and logistics issue is one of the priorities. Moreover, due to the fact that it offers a fairly quick connection between Central and Eastern Europe and the Far East (DP World Constanta, 2020), it also corresponds to the $17+1$ strategy. As a result of strategic investment and the deepening of relations between Romania and the United Arab Emirates, the UAE Embassy was established in 2004 in the Romanian capital, Bucharest. Over the next more than 10 years, relations between Romania and the UAE developed very well and steadily. It should be stated that in this period the relationship between Bulgaria as well as Romania and the UAE were not characterised by greater dynamics, both in the political, economic, or military dimension. However, it is worth emphasizing the visit in June 2009 paid by H.H. Sheikh Abdullah Bin Zayed Al Nahyan, Minister of Foreign Affairs and International Cooperation of the United Arab Emirates.

In 2014, due to the events in the Black Sea, in Ukraine, i.e. the annexation of Crimea, the countries of Central and Eastern Europe decided to tighten regional cooperation. In this context, in 2015, the concept of closer cooperation between the Adriatic Sea, the Baltic Sea, and the Black Sea emerged. At the same time, it should be recognized new impulses for their further deepening relations between Bulgaria and Romania with the United Arab Emirates. In May 2015, the Prime Minister of Romania, Victor Ponta, paid an official visit to the United Arab Emirates. During this visit and the talks at the highest level, the UAE's intention to undertake further investments in Romania, in particular in the agricultural sector, was announced. Moreover, the following agreements were signed during the Romanian Prime Minister's stay in the United Arab Emirates, i.e.an Agreement on mutual visa waiver for holders of diplomatic and special passports, and a Memorandum of Understanding regarding political consultations, higher education, and scientific research (MOFAIC, 2015). Consequently, a few months later, in January 2016, the Sharjah-based group Chemie-Tech DMCC announced its decision to invest \$ 63 million in Romania, in a factory that specialises in recycling used oil from the automotive industry. Moreover, it was emphasised that the UAE company plans to open a nationwide used oil collection network in Romania. It should be underlined that the project is the first investment of this type in Central and Eastern 
Europe (Banila, 2016). At the same time, in January, Bulgarian Minister of Information Technology and Communications, Ivaylo Moskovski came to Dubai. During the visit, after a meeting with the UAE Minister of Economy, Sultan bin Saeed Al Mansouri, an Agreement on air services was signed (WAM, 2016).

Map 1: Three Seas Initiative countries

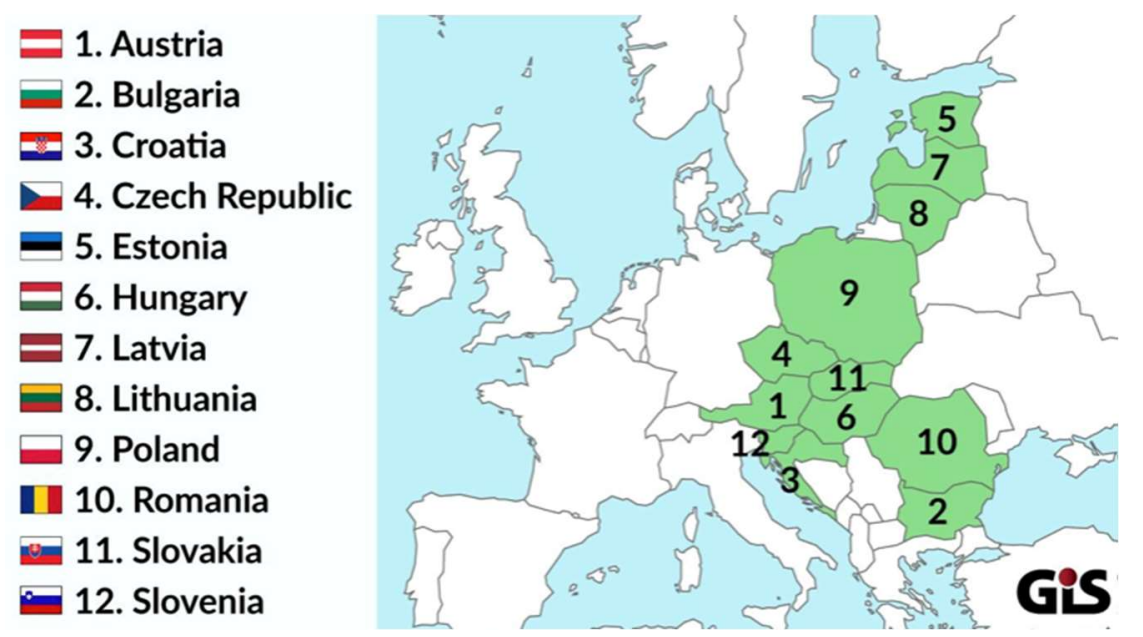

Source: https://www.gisreportsonline.com/97,i.html

The idea of closer cooperation between 12 countries located between the Adriatic Sea, Baltic Sea, and the Black Sea was formalized on August 25, 2016, by a signed Joint Declaration establishing the Three Seas Initiative. In October 2016 the UAE Minister of Economy visited Bulgaria. After the meeting with his counterpart, Bozhidar Lukarski, an Agreement on economic co-operation was signed (Tfaham, 2016). In the following year, 2017, Bulgarian Minister of Economy, Bozhidar Lukarski came to the United Arab Emirates, where, in addition to meeting with UAE Minister of Economy, Sultan Bin Saeed Al Mansouri, further were signed Agreements for Air Services and Establish Economic Relations. In April 2018, the Deputy Prime Minister and Minister of Foreign Affairs, Ekaterina Zakharieva, came to the United Arab Emirates. During this visit, an MoU on political consultations between the two ministries of foreign affairs was signed. Moreover, the official opening ceremony of the Bulgarian Embassy in Abu Dhabi took place. At the same time, in April 2018, the UAE Minister of Education, Hussain Al Hammadi, visited Romania to deepen relations between the two countries in the field of science and research. In 
order to make joint decisions, during the visit, a meeting was held with the Deputy Prime Minister of Romania, Viorel Stefan, Minister of National Education, Valentin Popa, and the heads of universities as well as research institutions (MOFAIC, 2018a). One month later, the UAE Minister of State, Sultan bin Ahmad Sultan Al Jaber arrived in Romania to chair together with the Minister of Foreign Affairs of Romania, Teodor Melescanu, the first-ever meeting of the UAE-Romania Joint Committee in Bucharest. The partners emphasised the need to further use the strategic position of both countries, especially in the context of the development of trade. In addition, numerous agreements were signed during the visit, including an MoU founding the UAE-Romania Joint Committee, an $\mathrm{MoU}$ on cooperation, and exchange of media information between the Emirates News Agency, the WAM, and the Romania News Agency. Moreover, an MoU on agricultural cooperation, an MoU on cooperation in the sports sector, an MoU to enhance bilateral investments and cultural cooperation have been signed. In addition, the UAE-based Al Dahra Agriculture company has started to make agricultural investments in the Black Sea region. This initiative is in line with the United Arab Emirates' strategy of ensuring food security, a country that imports over $90 \%$ of its food. It is also worth emphasising that the chairman of the UAE delegation during his stay in Romania met with all of the most important people in the country (MOFAIC, 2018b). As a consequence, a few months later, in September 2018, the Ruler's Representative in the Al Dhafra Region in the UAE, H.H. Sheikh Hamdan bin Zayed Al Nahyan came to Romania. In order to deepen relations, especially trade and investment, during the visit, meetings were held with, among others, President Klaus Iohannis and Prime Minister Viorica Dancila (Alfaham and Mohamed, 2018). Continuing relations at the highest level, the following month the Romanian Prime Minister Vasilica Viorica Dăncilă paid a visit to the United Arab Emirates, along with a large delegation, including ministers and businessmen. During a successful visit, the ministers of foreign affairs of both countries signed an Agreement between the two governments on reciprocal property ownership rights for the diplomatic missions. The partners have agreed to work even deeper, especially between various clusters, including automotive construction, high tech, agriculture and food, energy, aerospace, mechanical, electrical, creative and cultural sectors, tourism, IT\&C (including blockchain technology) health and medical sciences, constructions, maritime, textile, furniture, green energy, and logistics. As a result of dynamic relations at the highest level, both parties expressed their willingness to conclude a Strategic Economic Partnership in the near future (MOFAIC, 2018c). In October 2018, the Prime 
Minister of Bulgaria, Boyko Borisov, paid an official visit to the United Arab Emirates. During the visit, the leaders of both countries decided to take action to prepare an agreement on strategic cooperation and to strengthen relations in all areas of cooperation, especially political, economic, security, cultural, and sports (Embassy of the Republic of Bulgaria, 2018a). In addition, during the conversation with the Prime Minister of Bulgaria, Boyko Borisov, the Crown Prince of Abu Dhabi and Deputy Supreme Commander of the Armed Forces, H.H. Sheikh Mohammed Bin Zayed Al Nahyan stated that they identified many common strategic interests in the field of economy, agriculture, construction, technology, and the military industry. In the context of the Three Seas Initiative and the role and importance of Bulgaria not only in the Balkan region but also for the Middle East, the interviewees emphasised the special importance of the transport corridors that Prime Minister Borisov has been negotiating with other Balkan countries. In this sense, the leaders of both countries underlined that the strategic location of Bulgaria should be used for mutual benefits, as well as in a broader geopolitical sense for the development of trade and economic agreements of the United Arab Emirates in Europe (Embassy of the Republic of Bulgaria, 2018b). As a result of the visit of the Prime Minister of Bulgaria, Boyko Borisov to the UAE, the areas of cooperation between the two countries were significantly deepened and expanded. Only a few weeks later, further official visits were made to the United Arab Emirates. One of them was the visit of the Minister of Education of Bulgaria, Krasimir Valchev. Another visit of the Minister of Interior Affairs, Mladen Marinov from General Attorney Sotir Tsatsarov. In addition, the UAE Minister of Food Security, Mariam Al Muhairi, arrived in Bulgaria that same month. Just two months later, at the beginning of February 2019, the Minister of Interior Affairs, Mladen Marinov, and the General Attorney, Sotir Tsatsarov again visited the United Arab Emirates (Sofia News Agency, 2019). In March 2019 the Emirati company DP World Constanta, managing the strategic sea terminal Constanta South Container Terminal (CSCT) SRL in Romania, received a license renewal for another 30 years, i.e. until 2049 (MOFAIC, 2019a). Thanks to this decision, DP World from Dubai will have an important role and significance in the implementation of some strategic projects of the Three Seas Initiative for a long, crucial period. The implementation of the 3SI road connection via Carpathia, which will run near Constanta, will be another strategic value for the Constant South Container Terminal. 
Map 2: Three Seas Initiative projects

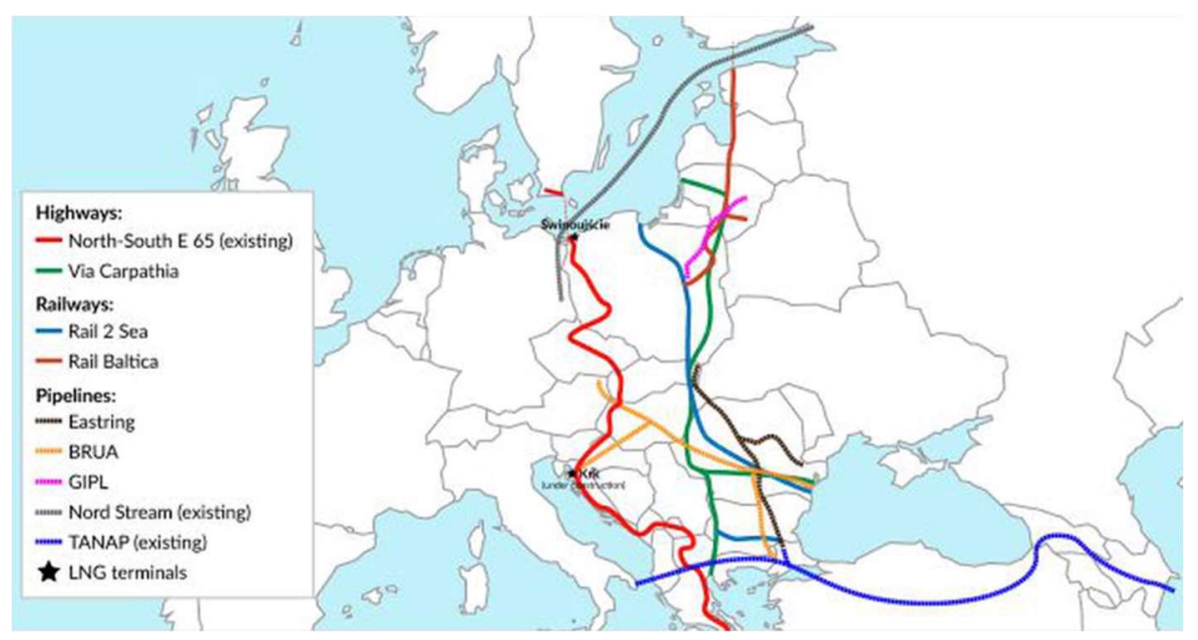

Source: $\quad$ https://www.gisreportsonline.com/regional-integration-at-the-three-seassummit,economy, 2683 ,report.html

Aiming to further deepen the relations between the states and concluding a strategic partnership, in June 2019 the Minister of Foreign Affairs and International Cooperation, H.H. Sheikh Abdullah bin Zayed Al Nahyan came to Romania. During this visit, His Highness held talks with, among others, the Prime Minister Vasilica Viorica Dăncilă and the Minister of Foreign Affairs of Bulgaria, Teodor Meleșcanu. The partners reviewed potential cooperation projects, including in the field of trade, agriculture, infrastructure, transportation, and Information and Communications Technology (MOFAIC, 2019b). In June 2019, a very important visit to Bulgaria took place, paid by the UAE Minister of Foreign Affairs and International Cooperation, H.H. Sheikh Abdullah Bin Zayed Al Nahyan, serving to clarify the scope of the strategic partnership. Moreover, during H.H. stay in Sofia, the UAE Minister, together with the Minister of Foreign Affairs of Bulgaria, officially opened the Embassy of the United Arab Emirates (Hussein and Salman, 2019). In order to deepen economic relations, the Deputy Prime Minister for Economic and Social Policy Mariyana Nikolova visited the UAE in February 2020. During the meeting with the UAE Minister of Economy, Sultan Bin Saeed Al Mansouri, they discussed many important 
issues, including supporting small and medium-sized enterprises and creating a joint venture (Sofia News Agency, 2020).

\section{Findings}

After 2011, the countries of Central and Eastern Europe gained a much more important role and position in the foreign and security policy of the United Arab Emirates. Studies of twelve countries of the Three Seas Initiative and the most important official bilateral visits demonstrate that in the last 20 years every member of this project has recorded a visit at the highest level in relation with the UAE.

The charts below show the dynamics of the most important official bilateral visits, at the level of heads of state and government as well as ministers of foreign affairs, the economy as well as members of the royal family holding high state positions were taken into account.

Figure 1: The most important official bilateral visits 2011-2015

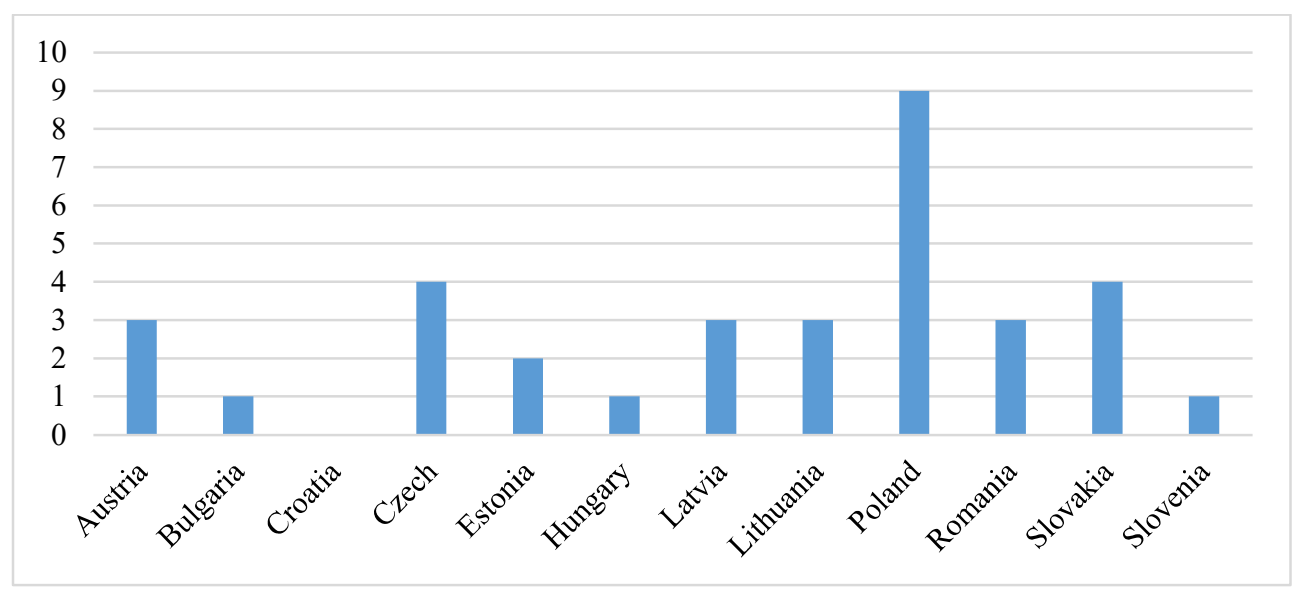

Source: Own study based on data from government institutions.

In the period 2011-2015, Bulgaria recorded one of the lowest levels of relations with the United Arab Emirates in terms of top-level visits. On the other hand, Romania showed the dynamics of bilateral official meetings slightly higher than the average of all countries. 
Figure 2: The most important official bilateral visits 2016-2020

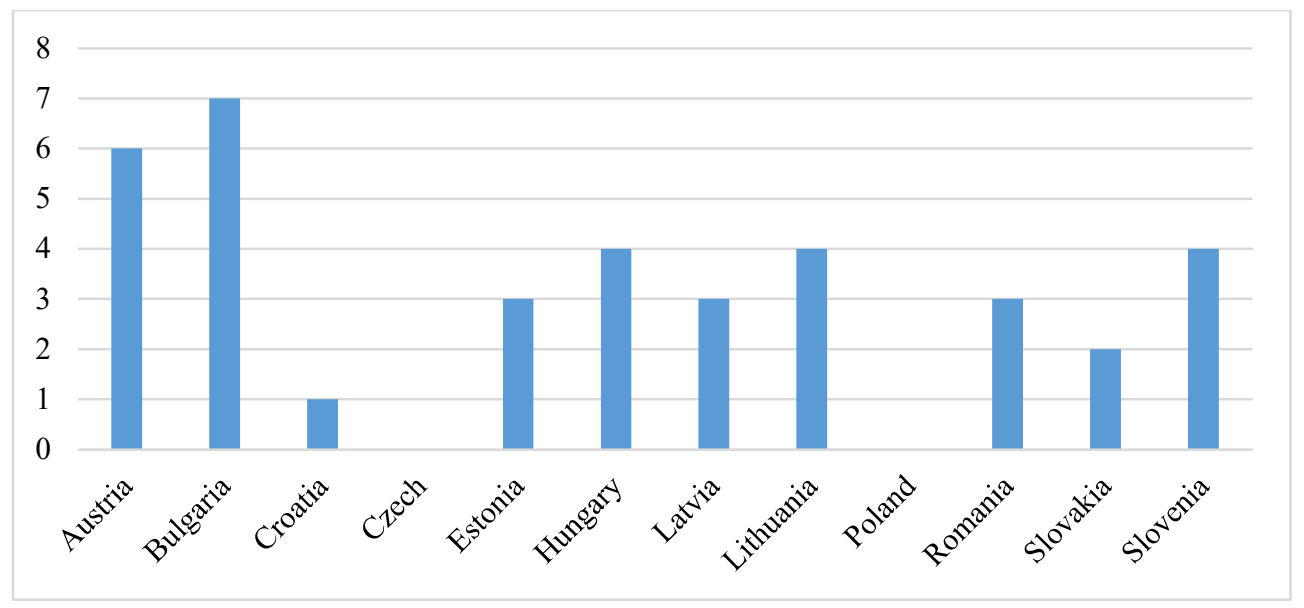

Source: Own study based on data from government institutions.

After 2015, during the implementation of the Three Seas Initiative, the vast majority of 3SI members demonstrate great dynamics. Bulgaria is the clear leader of this ranking. On the other hand, Romania recorded the same level of dynamics of official visits.

An analysis of the foreign and security policies of all partners, as well as their geostrategic situations and challenges, demonstrate that there is still a large potential for expansion and deepening of relations. It should also be noted that there has been a huge increase in top-level visits between Bulgaria and the United Arab Emirates since 2015, which may be explained by the need to diversify strategic alliances. Bulgaria recorded the highest number of top-level visits of all 12 Three Seas Initiative countries. The situation of Romania, which demonstrates the same level of dynamics of visits with the UAE in the last two decades, is the result of a lack of recognition of the need to conclude new strategic alliances. Romanian foreign and security policy wants to focus primarily on relations with the USA and strengthening the role and position within NATO and the European Union. However, it should also be emphasised that for both countries of the Three Seas Initiative, which are members of the North Atlantic Treaty Organisation and the EU, the United Arab Emirates is a country focused on close, strategic cooperation with the Euro-Atlantic area. In 2004, the same year Bulgaria and Romania joined the North Atlantic Treaty Organisation, and the United Arab Emirates became a member of the NATO Istanbul Cooperation Initiative. Besides, it should be noted that the United Arab Emirates is the first Arab country to have an ambassador accredited to NATO. Moreover, the UAE is deepening its relations with the European Union, for 
which the United Arab Emirates has become a strategic partner, as emphasised by the leaders of various European Union institutions. In addition, the United Arab Emirates creating a global new model of a green economy may be an interesting partner for Bulgaria and Romania in the implementation of the SDGs (Krzymowski, 2020, pp. 213-214). Therefore, the United Arab Emirates is an important strategic partner of the 3 SI countries in the Black Sea region.

\section{Geostrategic dimension}

When Ukraine and Georgia chose the Euro-Atlantic course of foreign and security policy, traditionally Bulgaria and Turkey began to support Russia in strategic projects (Joja, 2019, p. 14). Among all the Black Sea countries, Romania is a leader in spreading Euro-Atlantic values.

\section{Black Sea Strategy}

The beginning of the $21^{\text {st }}$ century is a period of important Romanian initiatives concerning the security of the region. Romania's foreign and security policy was based on two strategic goals, i.e. membership in NATO, which took place in March 2004, and accession to the European Union. On the one hand, this was due to the beginning of an increase in military power, influence, and demonstration by Russia, and on the other hand, it was important due to the instability of the Middle East and finally the beginning of the war in the not-so-distant Iraq in 2003. Under these circumstances, Romania intended to take an active position by initiating and organising the Black Sea Forum for Partnership and Dialogue (BSF) in Bucharest in June 2006, with the security of the region as one of its most important goals. A few months later, after Romania joined the European Union on January 1, 2007, this initiative became an EU project. In April 2007, during the German presidency in the European Union, Romania managed to push through the Black Sea Synergy project, which was to become an important element defining the EU's strategy towards the region. However, just a year later, on May 27, 2008, Poland and Sweden, as part of the European Union, initiated the Eastern Partnership, emphasising the EU's special relations with six countries, i.e. Armenia, Azerbaijan, Belarus, Georgia, Moldova, and Ukraine, which were included in the Black Sea Forum for Partnership and Dialogue (BSF) and Black Sea Synergy. Moreover, the Eastern Partnership has raised concerns about competition with these initiatives. Therefore, the European Parliament underlined the need to create a similar like the Mediterranean Union - the Union for the Black Sea (Piskorska, 2012, p. 190). As a result, as Joja (2019, p. 8) points out, both Romania's 
initiatives regarding the Black Sea basin did not bring the expected result. The European Union has not adopted a Black Sea Strategy. Besides, internal problems did not favour the effectiveness of its foreign policy and actions on the European Union forum. However, before the NATO summit in 2015 in Bucharest, Romania and Poland initiated cooperation of nine countries of NATO's eastern flank (B9) to deepen security cooperation not only within the North Atlantic Alliance but also in cooperation with the EU. In 2016, during the NATO summit in Warsaw, Romania took the initiative to establish a regional Black Sea Force. However, Bulgaria immediately announced that it was not interested in the project. In this way, Bulgaria blocked the implementation of this initiative, supporting a strong security guarantee by North Atlantic Treaty Organisation and enabling closer cooperation with countries aspiring to NATO from the region, i.e. Ukraine and Georgia. Additionally, Bulgaria has consistently continued its close strategic relations with Russia not only in the area of economy, investment, industry, and tourism but also by supporting Russian energy projects that make Europe dependent on gas from Russia through Turkish Stream, South Stream or Turkish Stream. In 2016, Poland and Croatia initiated the Three Seas Initiative (3SI), in which the Black Sea countries are an important part of it. The dynamics of this initiative shows its great potential and effectiveness in influencing both EU partners and the international environment.

Since 2011, Turkey has been taking active military operations in the Middle East and North Africa (MENA), mainly in Libya, Syria, Qatar, and Yemen. In addition, Turkey has established in Somalia the largest overseas military camp and in Sudan it leases the island of Suakin, deepening strategic relations with the country. For over 10 years, Turkey's foreign and security policy strategy has been based on the ideology of political Islam, which is operationally implemented primarily by the Justice and Development Party (AKP). Its goal is to establish Turkey as the political leader of the wider Muslim world (Occhiuto and Cafiero, 2020). Turkey, taking advantage of Qatar's conflict with other GCC members, has installed military forces in the Tariq Ibn Ziyad base in Qatar. Moreover, in Iraq, Ankara has established around 20 small bases, mostly of an intelligence nature. Additionally, in northern Syria, Turkey has six bases with a significant number of soldiers on a rotating basis. Moreover, Turkish diplomacy is a very active instrument in implementing geostrategic goals (Pivariu, 2020). 


\section{Bulgaria's foreign and security policy (2017-2021)}

Bulgaria's current foreign and security policy is implemented on the basis of the Government Program 2017-2021, which indicates that although active participation in the European Union and NATO is the highest priority, the document emphasises that both organisations do not always define Bulgaria's coherent roles and international position as well as geopolitical interests. In addition, the geostrategic situation requires taking into account many factors, including Brexit, the migration crisis from the Middle East and North Africa, growing populism in the region, terrorist threats, and the uncertain structure of relations between the USA, North Atlantic Treaty Organisation, and the EU. Moreover, Bulgaria is dependent on Russia in the energy area. In such a situation, the Bulgarian government emphasises the need to continue strengthening relations with Russia, while trying to obtain the position of a mediator in the Black Sea region between Euro-Atlantic partners and Russia (Kandilarov, 2019, pp. 1,3). It is worth noting that when analysing the Balkans in terms of energy security, as much as $80 \%$ of the energy infrastructure belongs to Bulgaria with the possibility of affecting a large part of Europe. Therefore, this issue has the highest priority of Bulgaria's economic, foreign, and security policy. In 2019, Bulgaria took some steps to diversify its energy supply. On May 31, 2019, the Minister of Energy of Bulgaria, Temenuzhka Petkova, announced that in June 2019, using the Greek LNG terminal in Revithoussa and the Greek-Bulgarian gas connection (Sidirokastro-Kułat), American LNG would flow to Bulgaria (Seroka, 2019b). On September 18, 2019, the state-owned company Bulgartransgaz, responsible for the gas transmission system, signed a contract with the Saudi Arkad consortium for the construction of approx. $500 \mathrm{~km}$ of the second section of the Turk Stream gas pipeline connecting Bulgaria and Serbia. The project is to be put into service in 2021 and its cost is estimated at EUR 1.1 billion. However, most of this amount is to be covered by a Saudi corporation, which will receive transit fees for 10 years after the pipeline will launch. Bulgaria, being completely dependent on Russian gas supplies, took some further steps in 2019 to try to change the situation, by acquiring American LNG from Greece and starting the construction of a new interconnector with Greece (IGB), which should be put into service after 2021. However, it should be noted that this project can only provide 9\% of Bulgaria's gas needs (Seroka, 2019a). Due to the direct sensitivity of Bulgaria's politics and economy to the increasing competition between Euro-Atlantic partners and Russia in the region, the country is increasingly interested in cooperation with China under the $16+1$ platform (now, after Greece's accession: $17+1$ ), especially 
in the context of Silk Road project. It is worth mentioning the strategic document 'Vision for Bulgaria', prepared by the Bulgarian Socialist Party, which is currently the second power in parliament, with an upward trend in support. This vision emphasises the need to deepen strategic relations with China and to establish a Global Partnership Centre in Sofia (Kandilarov, 2019, p. 5). Moreover, Bulgaria would like to use the IGB to be a Balkan Gas Hub, which would be used to transmit gas from directions other than Russia, and which would be directed to Central European countries. In this sense, a link between Bulgaria and Romania has been in operation since 2016, and the construction of the first section of the BRUA gas pipeline (Bulgaria-Romania-HungaryAustria) has been underway since June 2018. This is taking place under the influence of American lobbying, in the face of Russian influence (Seroka, 2019b). So, there is a huge competition going on between the USA and Russia to shape the energy security of a large part of Europe for many years. Moreover, the United States of America is involved in the Three Seas Initiative, for which energy security is one of its strategic priorities.

\section{Romanian National Security Strategy (2020-2024)}

On June 30, 2020, the Romanian parliament almost unanimously adopted the new National Security Strategy for 2020-2024, which sets the foundation for deepening strategic relations with the United States of America and strengthening its role and position in the European Union and NATO. For the first time, in Romania's security strategy, Russia was repeatedly explicitly mentioned as a country destabilising the situation in the Black Sea region. Romania recognises that Russia wants to use the EU's European Security and Defence Policy and attempts to build European strategic autonomy as a platform for implementing its foreign and security policy (Krzymowski, 2009, p. 30). Therefore, the strategy provides for actions aimed at increasing the US military presence in Romania. For this reason, the document emphasises the need to expand Romania's defence potential. Analysing the broader geostrategic aspect of military cooperation between the USA and Romania, in 2005 the two countries signed an agreement to provide Romania's military infrastructure to the US military forces, which is used for operations in the Middle East. It is worth mentioning that since 2007, Mihail Kogălniceanu's air force base has been located in Romania, near Constanta, where 1,300 American soldiers are stationed rotating. In addition, this base is an important multimodal transport hub for US military forces. In addition, its expansion and modernisation are planned, for which the Romanian government wants to allocate 
over 2.5 billion euros. Another important part of the United States of America activity is its military presence in the Air Force base at Câmpia Turzii, in which the Romanian government plans to invest $€ 200$ million, with additional USA support of \$ 130 million, to increase its operational capabilities. In addition, US soldiers use, among others, training grounds in Babadag, Cincu, and Smârdan. Meanwhile, since 2016, Devesel has three SM-3 missile batteries, the American antimissile defence system, and several hundred American sailors. In addition, an armoured battalion of the American armed forces has been stationed on a rotating basis since 2017 under an agreement with the USA. It should be emphasised that currently, Romania is primarily seeking to establish a permanent military presence of the US troops, rather than a rotational one (Całus, 2020). Also, worth emphasising is Romania's close military relations and military exercises with France and Germany, including those beyond the NATO formula, such as the Romanian French naval exercises, or the integration of the Romanian $81^{\text {st }}$ Mechanised Brigade with the German Rapid Response Forces Division. In this cooperation, both France and Germany are seeking Romanian arms contracts (Pieńkowski, 2019).

\section{Conclusion}

From the beginning of 2011, i.e. the start of the so-called Arab Spring, relations between the United Arab Emirates and the European Union members, especially with the countries of Central and Eastern Europe, intensified. Additionally, this process was favoured by the situation related to the implementation of the Treaty of Lisbon, including the establishment of new instruments of the Common Foreign and Security Policy and the change of priorities in the United States of America foreign and security policy, i.e. transferring political, economic and security strategic priorities from the Euro-Atlantic and Middle East area to the Pacific region.

The transport and economic strategic element of the Three Seas Initiative made it possible to connect Europe, the Baltic Sea with North and Sub-Saharan Africa, as well as the GCC countries through the Black Sea region. Thus, Bulgaria and Romania are important parts of the 3SI. Moreover, with the support of the United States of America, they may not only constitute a crucial element of the European political, economic, and security structure but also have a significance in the global dimension, especially in the area of North Africa and the Middle East (MENA), including GCC (Repetowicz, 2017). When analysing the Three Seas Initiative, it should be noted that the USA is interested in the implementation of 3SI, seeing it as an opportunity to pursue 
American interests in the LNG sector, and in a broader geopolitical dimension, combining this initiative with projects in the Middle East.

Analysing both the new National Security Strategy for 2020-2024 and the decisions and actions taken by the Romanian government and president, it should be emphasised that in the increasingly aggressive rivalry between the USA and China, Romania will definitely support the United States of America, believing that this country, in the long run, will remain the most influential country in the world. Especially since July 2020, the USA decided to strengthen the North Atlantic Treaty Organisation's south-eastern flank, including the Black Sea basin, and to increase the presence of American troops in this region. Moreover, in the emerging new global security architecture, a decisive factor will be the new identification of global interests by state actors, resulting in a new constellation of not only interests but alliances (Całus, 2020). Bulgaria, experiencing the dynamics of contemporary international relations, their multi-polarities, the complexity of the contemporary world economy, and the emerging new global security architecture, aims to diversify alliances. In this sense, the United Arab Emirates, anchored in the Euro-Atlantic partnership and possessing extensive influence, appears as an interesting strategic partner.

\section{References}

1. AlfAHAM, T. and MOHAMED, H. (2018) Hamdan bin Zayed visits Romania. WAM. Available at: http://wam.ae/en/details/1395302708370 [Accessed 15.04.2020].

2. BANILA, N. (2016) EBRD mulls lending $\$ 15 \mathrm{mln}$ to UAE's Chemie-Tech for oils recycling plant in Romania. Available at: https://seenews.com/news/search_results/?author=209 [Accessed 30.05.2020].

3. CAŁUS, K. (2020) Nowa strategia bezpieczeństwa Rumunii. OSW Analizy (202007-15). Available at: https:/www.osw.waw.pl/pl/publikacje/analizy/2020-07-15/nowa-strategiabezpieczenstwa-rumunii [Accessed 15.07.2020].

4. DP World Constanta (2020). Available at: https://www.dpworldconstanta.com/about/about-us [Accessed 14.07.2020]. 
5. EMBASSY OF THE REPUBLIC OF BULGARIA (2018a) Prime Minister Borissov Met with UAE Prime Minister Mohammed Bin Rashid Al-Maktoum. Available at: https://www.mfa.bg/en/embassies/uae/news/19825 [Accessed 14.07.2020].

6. EMBASSY OF THE REPUBLIC OF BULGARIA (2018b) Prime Minister Borissov Met with the Crown Prince of Abu Dhabi Sheikh Mohammed Bin Zayed Al-Nahyan. 2018. Available at: https://www.mfa.bg/en/embassies/uae/news/19824 [Accessed 17.04.2020].

7. HAZEM, H. and NOUR, S. (2019) Bulgaria's PM meets Abdullah bin Zayed. WAM. 2019. Available at: http://www.wam.ae/en/details/1395302767867 [Accessed 30.04.2020].

8. JOJA, I. S. (2019) The Black Sea: Strategic Volatility. Players and Patterns. Black Sea Strategy Papers. Eurasia Program Leadership. Foreign Policy Research Institute. Available at: https://www.fpri.org/wp-content/uploads/2019/10/jojabssp2.pdf [Accessed 30.05.2020].

9. JOJA, I. S. (2020) Three Conflict Scenarios for the Black Sea in 2020. January 7, 2020. Eurasia Program. Available at: https://www.fpri.org/article/2020/01/three-conflictscenarios-for-the-black-sea-in-2020/ [Accessed 15.07.2020].

10. KANDILAROV, E. (2019) Bulgaria External Relations Briefing: Foreign Policy and International Relations of Bulgaria 2019 - Outlook. Vol. 14, No. 4 (BG) January 2019. ChinaCEE Institute. Available at: https://china-cee.eu/wp-content/uploads/2019/04/2019er0156- (15Bulgaria.pdf [Accessed 14.04.2020].

11. KRZYMOWSKI, A. (2009) Plan Miedwiediewa - nowa architektura bezpieczeństwa?, Sprawy Międzynarodowe 2009, $\mathrm{nr}$ 2, 23-33. Available at: https://www.researchgate.net/publication/343140197_Plan_Miedwiediewanowa architektura bezpieczenstwa_Medvedev's_Plan - a a New Security_Architecture [Accessed 30.07.2020].

12. KRZYMOWSKI, A. (2020) Sustainable Development Goals in Arab Region United Arab Emirates' Case Study. Problemy Ekorozwoju - Problems of Sustainable Development 2020, vol. 15, no 1, 211-220. Available at: https://www.researchgate.net/publication/339271180_Sustainable_Development_Goals_in_Arab _Region_-_United_Arab_Emirates'_Case_Study[Accessed 14.05.2020]. 
13. KRZYMOWSKI, A. (2019) Water As A Weapon of War in the Tigris-Euphrates Basin. Przegląd Strategiczny 2019, Issue 12. DOI: 10.14746/ps.2019.1.20. Available at https://www.researchgate.net/publication/338928863 Water_as a Weapon_of War_in the Tig ris-Euphrates_Basin

14. MOFAIC. (2019a) DP World renews concession contract with Constanta port by 2049. Available at: https://www.mofaic.gov.ae/en/MediaHub/News/2019/3/19/19-03-2019-UAEBUCHAREST [Accessed 30.05.2020].

15. MOFAIC. (2019b) H.H. Sheikh Abdullah bin Zayed meets Romanian FM. Available at: https://www.mofaic.gov.ae/en/MediaHub/News/2019/6/13/13-06-2019-UAERomania [Accessed 11.05.2020].

16. MOFAIC. (2015) HH Sheikh Mohammed bin Rashid, Romanian PM hold talks, witness of signing agreements Available https://www.mofaic.gov.ae/en/MediaHub/News/2015/5/5/050515-1 [Accessed 11.04.2020].

17. MOFAIC. (2018a) Hussain Al Hammadi meets with Romanian officials. Available at: $\quad$ https://www.mofaic.gov.ae/en/MediaHub/News/2018/4/15/15-04-2018-UAE-Romania [Accessed 12.05.2020].

18. MOFAIC. (2018c) UAE, Romania agree to develop bilateral relations, social and economic cooperation. Available at: https://www.mofaic.gov.ae/en/MediaHub/News/2018/10/18/18-10-2018-UAE-Romania [Accessed 10.04.2020].

19. MOFAIC. (2018b) UAE-Romania Joint Committee holds its first meeting in Bucharest. Available at: https:/www.mofaic.gov.ae/en/MediaHub/News/2018/4/17/17-04-2018UAE-Bucharest [Accessed 30.04.2020].

20. OCCHIUTO, A. and CAFIERO, G. (2020) Turkey and the United Arab Emirates's Dangerous Collision Course. International Institute for Middle East and Balkan Studies. Ljubljana, Slovenia. Available at: https://www.ifimes.org/en/9868 [Accessed 30.05.2020].

21. PIEŃKOWSKI, J. (2019) Polityka obronna Rumunii - ambicje i możliwości. Biuletyn PISM $\mathrm{nr} 36$ (1784) 3 kwietnia 2019 r. Available at: https://www.pism.pl/publikacje/Polityka obronna Rumunii ambicje i mo liwo ci [Accessed 10.04.2020]. 
22. PISKORSKA, B. (2012) „Synergia czarnomorska”: zbliżenie państw regionu Morza Czarnego do Unii Europejskiej, p. 190.

23. PIVARIU, C. (2020) Turkey: Erdogan seeks to achieve the dream of the empire's rebirth. International Institute for Middle East and Balkan Studies. Ljubljana, Slovenia.

24. REPETOWICZ, W. (2017) Trump w Polsce: Trójmorze a Bliski Wschód. Defence24. Available at: https://www.defence24.pl/trump-w-polsce-trojmorze-a-bliski-wschodanaliza [Accessed 15.04.2020].

25. SEROKA, M. (2019) Butgaria: nowa formuła gazociagu South Stream. OSW Analizy (2019.09.25). Available at: https:/www.osw.waw.pl/pl/publikacje/analizy/2019-0925/bulgaria-nowa-formula-gazociagu-south-stream [Accessed 30.04.2020].

26. SEROKA, M. (2019b)_Bułgaria: Dywersyfikacja źródeł dostaw gazu ziemnego. OSW Analizy (2019.06.05). Available at: https://www.osw.waw.pl/pl/publikacje/analizy/201906-05/bulgaria-dywersyfikacja-zrodel-dostaw-gazu-ziemnego [Accessed 30.04.2020].

27. SOFIA NEWS AGENCY. (2019) Bulgaria's Chief Prosecutor and Interior Minister are on a Visit to Abu Dhabi. Sofia News Agency. 2019. Available at: https://www.novinite.com/articles/194980/Bulgaria's+Chief+Prosecutor+and+Interior+Minister + are + on $+\mathrm{a}+$ Visit + to + Abu+Dhabi [Accessed 17.05.2020].

28. SOFIA NEWS AGENCY. (2020) Mariana Nikolova: The UAE is an Important Foreign Trade Partner of Bulgaria. 2020. Available at: https://www.novinite.com/articles/203186/Mariana+Nikolova\%3A+The+UAE+is+an+Important + Foreign + Trade + Partner + of + Bulgaria [Accessed 30.05.2020].

29. WENDT, A. (1987) The Agent-Structure Problem in International Relations, International Organization, 41, 3, 335-70.

30. TFAHAM. (2016) UAE seeking greater co-operation with Bulgaria: Al Mansouri. WAM. Available at: http://wam.ae/en/details/1395301204222 [Accessed 17.04.2020].

31. WAM. (2016) UAE inks air services agreement with Bulgaria. MMYS. Available at: http://wam.ae/en/details/1395290816680 [Accessed 30.04.2020]. 